\title{
MINŐSÉGI FELSŐOKTATÁS VS. MINŐSÉGI DIPLOMA, AVAGY A HUMÁNTŐKÉBE VALÓ KÉPZÉSI BEFEKTETÉS HASZNOSULÁSA MUNKAERÖ- PIACI ASPEKTUSBÓL
}

\author{
Mikáczó Andrea $\mathbf{P h D}^{1}$, Varga Erika $\mathbf{P h D}^{2}$ \\ ${ }^{1}$ egyetemi docens $-{ }^{2}$ tanársegéd \\ Szent István Egyetem, Gazdaság- és Társadalomtudományi Kar \\ Üzleti Tudományok Intézete - Társadalomtudományi Intézet \\ H-2100 Gödöllö, Páter Károly u. 1.
}

\section{Összefoglalás}

A tanulmány arra kíván rávilágítani, hogy a fiatalok munkaerő-piacra való kilépéséhez, az azon való érvényesüléshez milyen eszközök, módszerek, lehetőségek közül válasszanak oly módon, hogy az számukra a lehető legkedvezőbb megoldást eredményezze.

A tanulásnak/tudásnak tulajdonított jelentőség társadalmi megítélése változó képet mutat, az viszont vitathatatlan, hogy mind Magyarországon, mind szerte a világban az életen át tartó tanulásban (lifelong learning - LLL) rejlő lehetőségek jelenthetik az oktatási-képzési tevékenységek dinamizálásának és versenyképességének kulcsát.

\begin{abstract}
Our paper is aimed at highlighting and trying to find answers to the questions what methods, instruments and possibilities there are at the disposal of the young in order to gain the best result possible when entering the labour market and wishing to be successful there.

The significance attributed to studying/knowledge by society shows a varied picture although it is evident that the opportunities hidden in lifelong learning ( $L L L)$ either in Hungary or all over the world can mean the key to dynamising education and training as well as being competitive.
\end{abstract}

Kulcsszavak: oktatáspolitika, felsőoktatás, felsőoktatási szakképzés, duális képzés, munkaeröpiac, humántőke

\section{JEL besorolás: J24}

\section{Bevezetés}

Mit látnak, érzékelnek a szülők, a középiskolások, az érettségit nem szerzett fiatalok, a már diplomások és a jelenlegi hallgatók a magyar felsőoktatásból?

Bizonyos értelemben magától értetődő, ha pozitív képet látnak, hiszen olyan hagyományos értékekhez köthetik, mint a tudás, müveltség, kultúra. Sokak számára a társadalmi felemelkedést jelentik a felsőfokú tanulmányok. A vonzó képet visszaigazolja a mai napig jellemző túljelentkezés és a tény, hogy az elit számára ma is magától értetődik a felsőfokú diploma. Orvos, ügyvéd, tanár, mérnök sem lehet sikeres felsőfokú tanulmányok nélkül. 
A felsőoktatásról alkotott kép árnyékos oldalához tartozik azonban, hogy számos szakon szerzett végzettség nem biztosítéka egy fiatal számára a tisztes megélhetésnek, a munkaeröpiacon való gyors és könnyü érvényesüléshez, és a képzés tartalmát is sok kritika éri.

A felsőoktatási expanziónak két egyértelmü hatása volt: egyfelől ki kellett elégíteni a munkaerőpiac igényeit, aminek olyan képzett munkaeröre volt szüksége, amelyik rögtön alkalmazható, másfelöl megnyílt a lehetőség a hátrányos helyzetü rétegek vagy a szakmai középiskolában érettségizettek felsőoktatási részvételére is (Csehné, 2014).

Manapság már egyre inkább átértékelődik tudás, a felgyorsult és radikálisan kiszélesedő információszerzés korában a hosszú évekig folytatott tanulmányok már nem tünnek magától értetődőnek, és célszerünek, de egyben gazdaságossági kérdéseket is felvet a tanulmányi idő hossza, a tanulmány jellege/típusa (Bálint - Polónyi - Siklós, 2013).

A felsőoktatásban való részvétel egyéni és közösségi előnyei elvitathatatlanok, a diplomaszerzés nemcsak az egyén életútjára gyakorol jelentősen pozitív hatást, de a fenntartható növekedés egyik legfontosabb kulcstényezője is a tudás, avagy a humántőkébe való képzési befektetés.

A tanulmány annak bemutatására fókuszál, hogy a Bologna-képzési rendszer által kínált felsőoktatási képzési struktúrán túlmutatóan melyek a humán tőkébe való befektetési lehetőségek új dimenziói (felsőoktatási szakképzés, duális képzés), és ehhez a jelenlegi hazai oktatáspolitikai célkitüzések miként fognak tudni hozzájárulni.

\section{Anyag és módszertan}

A tanulmány alapvetően a felsőoktatási tevékenységeket leíró, szabályozó dokumentumok, jogforrások empirikus elemzésén alapul, amelyhez a vizsgált témakörben készült további szakirodalmak is feldolgozásra kerülnek kitérve egyes kapcsolódó statisztikai adatok szekunder elemzésére is.

\section{Eredmények}

\section{A magyar felsőoktatási rendszer átalakitásának szükségszerüsége}

Az elmúlt 25 év során Magyarország törlesztette a felsőoktatás sok évtizedes adósságát a társadalom, a családok irányába. Az elmúlt negyed évszázadban a felsőoktatáshoz való hozzáférés kiszélesedett, a képzésböl a korábbi évtizedekben kizárt csoportok megszerezhették a kívánt végzettséget, kialakult az egységes magyar felsőoktatás intézményrendszere és képzési szerkezete, visszaállt az oktatás és kutatás egysége, valamint megjelent a felsőoktatás minőségi fejlesztésének igénye.

A felsőoktatáshoz való hozzáférés lehetősége mind gazdasági, mind társadalmi szempontból jelentősen javult. 1990-ben az elitista 106 ezres felsőoktatás fokozatosan kinyílt, 15 évvel később már négyszer ennyi diák volt benne. Ma már nincs Magyarországnak olyan pontja, ahonnan ne lenne elérhető felsőoktatási intézmény egy órán belül, ez rendkívüli eredménynek tekinthető európai mércével mérve.

Ez az átalakulási folyamat - a fenti pozitívumok mellett - olyan módon és olyan elemeket tartalmazva zajlott le (a bolognai rendszer kritika nélküli implementációja, a tömegképzés 
érdemi kontroll nélküli támogatása, a munkaerőpiac igényeitől való eltávolodás, a felsőoktatási autonómia hibás értelmezése, az intézményi integráció és a képzési szerkezet átgondolatlan kialakítása), amely a felsőoktatás szinte minden elemében egy alacsony hatékonysággal müködő rendszeréhez vezetett (Topár, 2008).

Áttekinthetetlen, gazdaságtalanul felépített szakstruktúra, alkalmanként értéktelen diplomák, pazarló intézményrendszer, csökkenő oktatói, kutatói és hallgatói teljesítmény, széleskörü jogosítványokkal, de alacsony kötelezettséggel bíró rendszerek mind az intézmény irányításában, mind a hallgatói területen.

A hazai felsőoktatásnak fel kell vennie a globális világ által megkívánt tempót, mégpedig úgy, hogy a rendszerben lévő lehetőségek kiaknázásával, az értékmegőrzés és értékteremtés szem előtt tartásával, az erőforrások hatékony felhasználása mellett egy magasabb minőséget nyújtó, teljesítményelvü és a gazdasági szereplők igényeit is kiszolgáló rendszer jöjjön létre.

A munkaerö-piaci igényeknek megfelelő képzésazt jelenti, hogy az intézmények akkor teljesítik a feladatukat, ha a hallgatóknak átadott ismeretek a munkaerőpiacon relevánsak, a társadalom és a nemzetgazdaság számára egyaránt hasznosak, és ha az ország minden régiójában kellő számú, megfelelő végzettséggel rendelkező szakember áll rendelkezésre. Ennek érdekében az ország képzési szerkezete átalakítást és hatékonyság növelést kíván.

Az egyetemi hallgatók életcéljai között felértékelődni látszik a személyes fejlődési lehetőség, a harmonikus társas viszonyok fenntartására való törekvés, szemben a gazdasági vagy munkahelyi státuszhoz kapcsolódó előnyökkel. (J.Klér A., 2013.)

A felsőoktatás fenntartatója olyan racionalizációs folyamatokat indított el, amelynek eredményeként folyamatosan, felmenő rendszerben kivezetésre kerülnek az elhelyezkedést nem elősegítő képzések (pl.: társadalmi tanulmányok alapképzési szak, müszaki menedzser alapképzési szak), illetve ezek állami ösztöndíjjal való támogatása is megszünik, ugyanakkor ezek helyébe új képzési formák lépnek be, és törekszik a felsőoktatás és a szakképzés közötti átjárhatóság kedvezőbb feltételeinek megteremtésére. A jelenlegi elképzelések szerint 10-15 százalékkal csökkenhet a megszerezhető felsőoktatási szakképesítések száma a 2016-os felvételi eljárástól kezdődően, azaz a jelenleg müködő, 2005-ben létrehozott és azóta folyamatosan bővülő 658 szak helyett a jövőben ez a szám 550 körüli értékre fog csökkenni.

1. táblázat: Felsőoktatási fejlesztési indikátorok

\begin{tabular}{|l|c|c|}
\hline \multicolumn{1}{|c|}{$\begin{array}{c}\text { TELJESÍTMÉNY- } \\
\text { MUTATÓ }\end{array}$} & $\begin{array}{c}\text { KIINDULÁSI ÉRTÉK } \\
\text { (2013) }\end{array}$ & CÉLÉRTÉK (2020) \\
\hline $\begin{array}{l}\text { A meghirdetett képzések } \\
\text { száma az érintett } \\
\text { kapacitások megtartása } \\
\text { mellett országosan 15\%- } \\
\text { kal csökken }\end{array}$ & 10732 & 9122 \\
\hline $\begin{array}{l}\text { A lemorzsolódás aránya } \\
10 \text { százalékponttal } \\
\text { csökken az alap- és } \\
\text { osztatlan képzés átlagában }\end{array}$ & $35 \%$ & $25 \%$ \\
\hline Külföldi hallgatók száma & 23000 & 40000 \\
\hline
\end{tabular}




\begin{tabular}{|l|c|c|}
\hline $\begin{array}{l}\text { A duális alapképzésben } \\
\text { résztvevő hallgatók aránya } \\
\text { a releváns képzési } \\
\text { területeken az elsőévesek } \\
\text { körében }\end{array}$ & $0 \%$ & $8 \%$ \\
\hline $\begin{array}{l}\text { A felsőfokú vagy annak } \\
\text { megfelelő végzettséggel } \\
\text { rendelkezők aránya a 30- }\end{array}$ & $29,9 \%(2012)$ & $35 \%(2023)$ \\
34 éves népességen belül & & \\
\hline $\begin{array}{l}\text { Külföldi részképzésben, } \\
\text { legalább 3 hónap, vagy } \\
\text { minimum 15 kredit értékü } \\
\text { külföldi utazás vagy } \\
\text { szakmai gyakorlat } \\
\text { keretében részt vevő } \\
\text { hallgatók aránya }\end{array}$ & $10,41 \%$. (2012) & $20 \%(2023)$ \\
\hline
\end{tabular}

Forrás: http://www.kormany.hu/download/d/90/30000/felsoktatasikoncepcio.pdf; 2015

Az oktatás világa és a munkaerőpiac közötti átmenet zökkenőmentes biztosítása érdekében a jövő tekintetében előnyben részesülnek a projekt alapú, egyéni hallgatói munkavégzést igénylő oktatási formák, a munkaerőpiacon elvárt készségek beemelésre kerülnek a tantervekbe, kiszélesedik a duális felsőfokú képzés, reform alá kerül a felsőoktatási szakképzési rendszer, és várhatóan felsőoktatási és ipari együttműködési központok jönnek létre (Anwar M., 2011).

A felsőoktatási intézmények érzik, és belátják, hogy ennek az átalakításnak itt volt az ideje. A célkitüzés, hogy a jelenlegi 23 százalékról 35 százalékra tornásszák fel a diplomások arányát. Ám megváltozik a bemenet is: 2020-tól már a felvételi előfeltétele lesz egy középfokú nyelvvizsga.

A vállalatok a következő 3-5 évre tekintve felsőoktatási szinten fejlödésük legnagyobb akadályát abban látják, hogy nincsen elég müszaki szakember. Hiányt szenvednek közlekedésmérnökből, villamosmérnökböl, gépészmérnökböl, jármümérnökből, de a vegyészmérnök, az agrárszakember és bizonyos területeken a pénzügyi szakember is keresett a munkaerőpiacon továbbra is. Ezek a hiányszakmák jelzik, hogy merre kellene elmozdulnia a hazai felsőoktatásnak. A hiány azonban elsősorban nem mennyiségi, sokkal inkább minőségi. A legnagyobb baj, hogy a megszerzett elméleti tudás gyakorlati alkalmazásában nincsen kellő tapasztalatuk a végzetteknek. Ezen probléma megoldásához kínál lehetőséget a Németországban már az 1970-es évek óta sikeresen müködő modell, a duális képzés, amelyet rendszeresen, nemzetközi összehasonlításban mért eredmények is bizonyítanak.

A duális képzési forma olyan gyakorlatorientált képzés, amely során a hallgató már egyetemi évei alatt részletes ismereteket szerez a munka világáról, szocializálódik a későbbi vállalati, üzemi, szervezeti feladatokra, a szakmai gyakorlóhelyen töltendő megnövekedő időben pedig közvetlenül megismerheti és részesévé válhat a munkafolyamatoknak, lehetősége nyílik a szakmai kompetenciák gyakorlására(Hrubos, 2012).

A duális képzés tehát a gyakorlatigényes alapképzési szakon folytatott képzés azon formája, amelyben a szakmailag minősített vállalatoknál folytatható gyakorlati képzések tantervi tartalmuknál, struktúrájuknál és a vállalatoknál töltendö, megnövelt óraszámuknál fogva 
növelik a hallgatók szakmai kompetenciáját, vállalati üzemeltetési ismereteit és vállalati kultúráját.

A vállalatokkal a felsőoktatási intézmények kötnek együttmüködési megállapodást a képzésben történő részvételre. A vállalat és a hallgató pedig hallgatói munkaszerződést köt: a vállalat a képzés teljes idejére köteles díjazásban részesíteni a hallgatót (tehát mind a vállalati, mind az intézményi periódusok alatt). A díj mértéke legalább hetente a kötelezö legkisebb munkabér minimálbér - 15\%-a (tehát havonta legalább a minimálbér 60\%-a körüli összeg).

A duális képzési formájú szakokra történő jelentkezés a 2015-ös felvételi eljárásban két, egymással párhuzamos szakaszból áll: az állami, általános felvételi eljárásból (mely semmiben nem különbözik a nem duális szakokra való jelentkezéstől), és egy vállalati felvételi szakaszból.

A duális képzési rendszer elterjesztése által az elkövetkező időszakban olyan hallgatók kerülnek ki nagy számban a felsőoktatásból, akik azonnal, több éves továbbképzés, és további anyagi ráfordítás nélkül képesek belépni a munka világába. A képzési modell alkalmazásával várhatóan csökken a lemorzsolódók aránya, élénkül a gyakorlatorientált képzések ösztönzése, illetve a valós munkaerő-piaci igényekhez igazodó diploma kerül kibocsájtásra.

A 2015/2016 tanévben 21 felsőoktatási intézmény 79 alapképzési szakán indul el duális képzés. Az intézmények összesen 30 különböző típusú alapképzési szakot indítanak duális formában müszaki, informatikai, agrár, természettudomány és gazdaságtudományok szakterületeken. Az alapképzési szakok mellett a Budapesti Corvinus Egyetem próba jelleggel mesterképzést is indít duális formában. Ennek köszönhetően 2015 szeptemberétől akár 1000 hallgató kezdheti meg tanulmányait duális felsőoktatási képzéseken. Az intézmények több mint 350 külső partnerrel (gazdasági szervezettel) kötöttek együttmüködési megállapodást (ebből 248 kis- és középvállalat), amelyekhez a hallgatók beadhatják jelentkezésüket.

A képzések szeptemberi indításáig a Duális Képzési Tanács határozza meg azokat a követelményeket, amelyek a felsőoktatási duális képzésben a szakmai gyakorló helyként közremüködő vállalattól, szervezettől, illetve a gyakorlati képzésben résztvevő szakembertöl elvárhatóak.

A képzőhelyek minőségbiztosítása azért kulcsfontosságú, mert a duális képzésben a külső gazdasági szervezetek feladatai közé nemcsak a gyakorlati hely biztosítása tartozik, hanem a hallgatók formális képzése is.

Annak érdekében, hogy ez a modell hatékonyan müködjön, és még inkább népszerüvé válhasson biztosítja a Kormány, hogy a képzés azon költségei, amelyek a vállalatoknál jelentkeznek, le lehessen írni a szakképzési hozzájárulásból, továbbá biztosítja a hallgatói szerződések - amit a hallgatók és a vállalatok kötnek - járulékmentességét, és még további kedvezmények is kilátásban vannak.

2015 őszétől a következő intézmények indítanak duális felsőoktatási képzéseket:

1.Budapesti Corvinus Egyetem

2.Budapesti Gazdasági Főiskola

3.Budapesti Kommunikációs és Üzleti Főiskola

4.Debreceni Egyetem

5.Dunaújvárosi Főiskola

6.Eötvös József Főiskola 
7.Gábor Dénes Főiskola

8.Kaposvári Egyetem

9.Károly Róbert Főiskola

10.Kecskeméti Főiskola

11.Miskolci Egyetem

12.Nyíregyházi Főiskola

13.Nyugat-magyarországi Egyetem

14.Óbudai Egyetem

15.Pannon Egyetem

16.Pécsi Tudományegyetem

17.Széchenyi István Egyetem

18.Szegedi Tudományegyetem

19.Szent István Egyetem

20.Szolnoki Főiskola

21.Tomori Pál Főiskola

A képzések szeptemberi indításáig a felsőoktatási intézmények számára célzott európai uniós forrás áll rendelkezésre a duális képzések fejlesztésére. A kormányzat elindította el a TÁMOP 4.1.1.F-15/1/Konv pályázatot, amely kifejezetten a képzések, illetve tananyagok, taneszközök, illetve az intézmény és a partnerszervezetek közötti oktatási együttmüködési kapcsolatok fejlesztésére szolgál.

A pályázat keretösszege 2200000000 forint, amely a konvergencia régiókban használható fel, az igényelhető támogatás összege legalább $200000000 \mathrm{Ft}$, de legfeljebb $400000000 \mathrm{Ft}$ lehet. pályázhatnak.

A pályázat egyik fő célja a duális képzési rendszer elterjesztése az alapképzés és a felsőoktatási szakképzés területén. Legfontosabb célkitüzései között szerepel a gyakorlatorientáltság növelése a képzési tartalomban és módszerekben, a felsőoktatási képzések keretében a munkaerőpiac-orientált, vállalkozói kompetenciák fejlesztése, valamint a felsőoktatási képzés kooperatív duális rendszerüvé alakítása. (EMMI Felsőoktatásért Felelös Államtitkárság)

\section{A felsőoktatási szakképzés általános jellemzői}

A nemzeti felsőoktatásrólszóló 2011. évi CCIV. törvény (Ftv.)113. § (4) bekezdés szerint: „A 2005. évi felsőoktatási törvény alapján nyilvántartásba vett felsőfokú szakképzés 2012 szeptemberét követően nem indítható. A már megkezdett képzések változatlan feltételek mellett kifutó rendszerben - de legfeljebb a 2015/2016-os tanévben - fejezhetők be.”

Tehát megszünt a felsőfokú szakképesítés intézménye, helyette bevezetésre került a felsőoktatási szakképzés. A felsőoktatási intézmények által hallgatói jogviszony keretében folytatott szakképzés felsőfokú szakképzettséget ad, újabb végzettségi szintet azonban nem, azaz a felsőoktatási szakképzésben felsőfokú szakképzettséget tanúsító oklevelet lehet szerezni. A felsőoktatási szakképzés besorolási alapszakján való továbbtanulás esetén a felsőoktatási szakképzés képzési és kimeneti követelményeiben meghatározott kreditek 75 százalékát el kell ismerni, ez egy 120 kredites felsőoktatási szakképzés esetében azt jelenti, hogy a továbbtanulásnak megfelelő alapképzési szakon 90 kreditet be kell számítani. 
A képzési idő legalább négy félév, kivéve, ha az európai uniós jog valamely képzés tekintetében ennél hosszabb időt állapít meg, ebből egy félév egybefüggő szakmai gyakorlat a szakképzettségnek megfelelő munkakörben és munkahelyen.

A felsőoktatási szakképzés célja a munkaerő-piaci igényekhez igazított gyakorlatias, speciális szaktudást igénylő szakemberek képzése. Az elméleti és gyakorlati képzés aránya: 40\%-60\%

Milyen elönyei vannak a felsőoktatási szakképzésnek?

- két év alatt bizonyítvány által igazolt felsőfokú szakképzettség szerezhető;

- lehetőséget ad az elhelyezkedésben és a munkavállalás során elvárt első munkatapasztalatok megszerzésére;

- továbbtanulás esetén a tanulmányi eredményeknek egy része beszámítható;

- a felvett hallgatót ugyanolyan jogok illetik meg, mint az alapképzési szakra felvett diákokat, jár neki diákigazolvány és jogosult diákhitelre is.

\section{A középfokú szakképzés dilemmái}

Napjainkban a pályakezdők munkaerő-piaci helyzete az egyik legkérdésesebb. Gyakran e társadalmi csoport elvárásai és képességei nem igazán találkoznak a munkáltatók elvárásaival, és ez is az oka annak, hogy a pályakezdők munkaerő-piaci elhelyezkedése sok problémát és feladatot vet fel (Czeglédi Cs. - Juhász T., 2015).

A Magyar Kereskedelmi és Iparkamara (MKIK) és az MKIK Gazdaság- és Vállalkozáskutató Intézet (GVI) évente megismételt kérdőíves felmérésben 2009 és 2012 között több, mint 10000 olyan fiatal pályáját követte, akik szakiskolában vagy szakközépiskolában szereztek szakmát.

A kutatási eredmények (1. ábra) azt mutatják, hogy a szakképzett pályakezdők elhelyezkedési esélyeit leginkább az javítja, ha olyan szakmát tanultak, amely megfelel érdeklödési körüknek, és amivel később is szívesen foglalkoznának. A megfelelő szakmát tanultak 48 százaléka, míg a nem megfelelő szakmát végzetteknek csak 33 százaléka dolgozott a kérdezés időpontjában. Azaz nagyobb arányban sikerült elhelyezkedniük azoknak, akik érdeklődésüknek és tehetségüknek megfelelöbb szakmát szereztek.

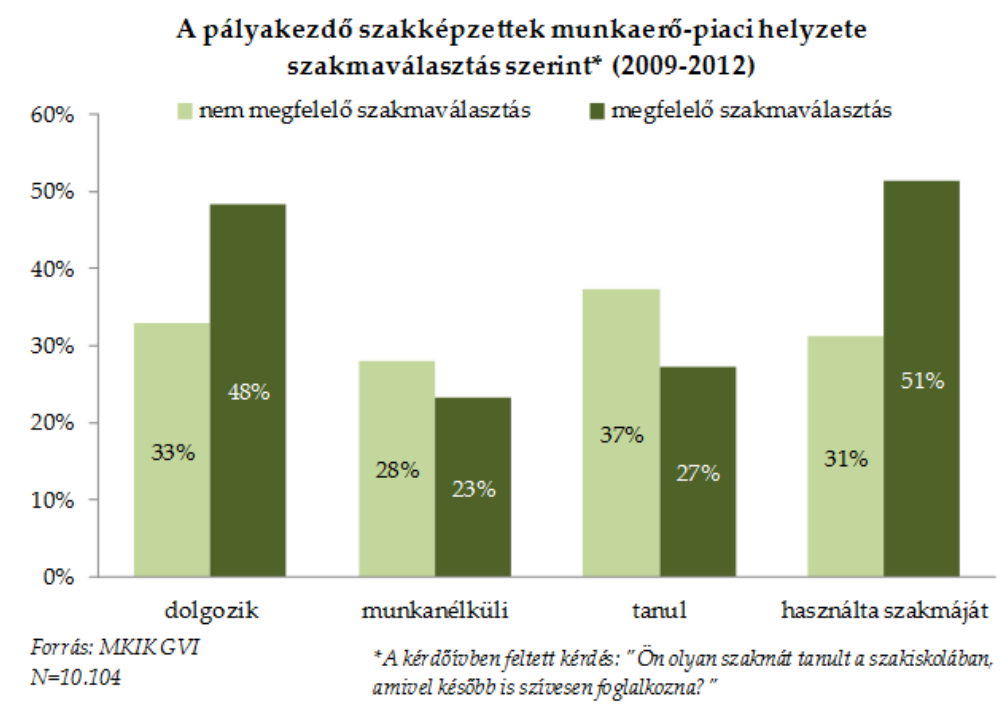

1. ábra: A pályakezdő szakképzettek munkaerő-piaci helyzete szakmaválasztás szerint

Forrás: MKIK GVI

(2009-2012) 
A gyakorlati képzést külső cégnél elvégzők - a cégekkel tanulószerződést kötők - is könnyebben tudnak elhelyezkedni. Azok közül, akik csak az iskolai tanmühelyben végezték gyakorlati képzésüket, 41 százalék talált munkát 9 hónap alatt, ez az arány a külső céghez járók körében 46 százalék, a mindkét helyre járók között pedig 49 százalék. A jó szakiskolai tanulmányi eredménnyel rendelkezők is jobb esélyekkel indulnak álláskereséskor: a munkába álltak tanulmányi eredményének átlaga 3,68, a többieké pedig csak 3,60 volt (2.ábra).

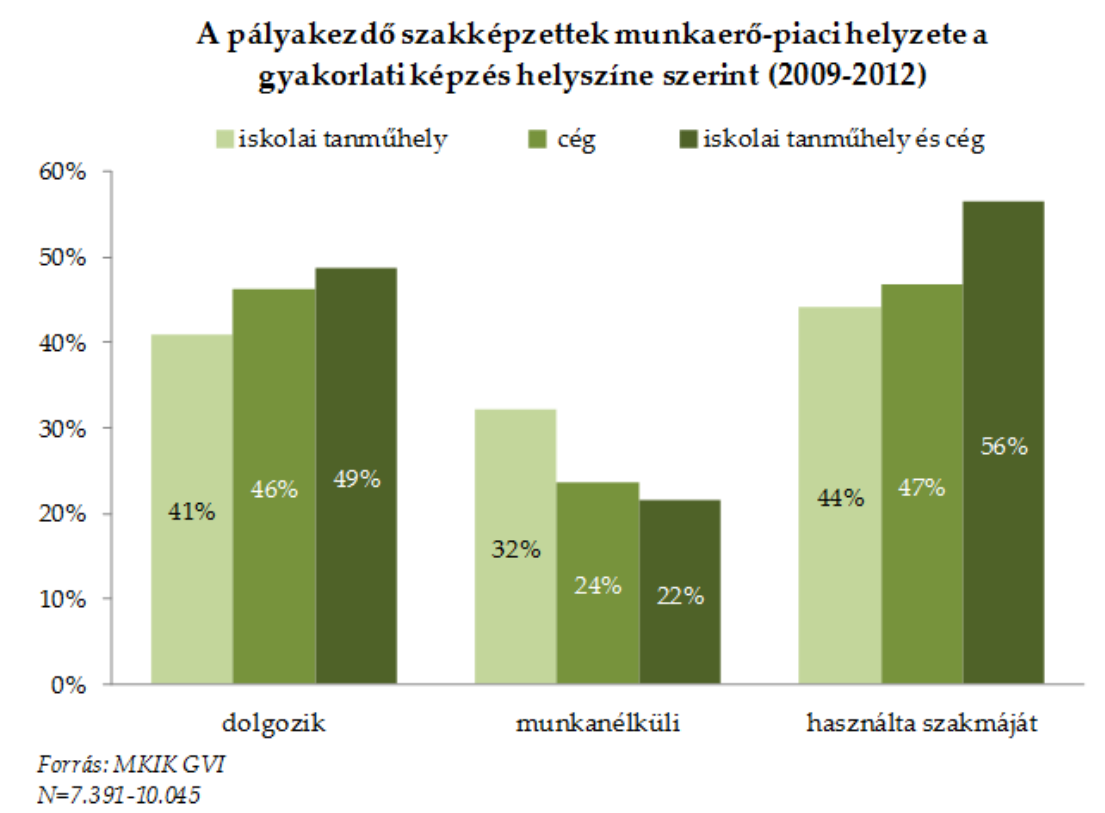

\section{2. ábra: A pályakezdő szakképzettek munkaerő-piaci helyzete a gyakorlati képzés helyszíne szerint (2009-2012)}

\section{Forrás: MKIK GVI}

Emellett a férfiaknak és a gépészeti szakmát tanultaknak is nagyobb esélyük van a 9 hónapon belüli elhelyezkedésre. A gazdasági válság óta egyre nehezebb munkaerő-piaci helyzet 2009 után azonban minden évben rontotta a pályakezdő szakképzettek elhelyezkedési esélyeit.

A munkanélküliségi kockázat esetében jelentős a családi háttér hatása: az alacsony végzettségü és a munkanélküli apák gyermekei gyakrabban válnak munkanélkülivé. Az érdeklődési körüknek megfelelő szakmát végzettek körében alacsonyabb (23 százalék) a munkanélküliség, mint azok között, akik nem szívesen foglalkoznának a jövőben a megelöző évben szerzett szakmájukkal (28 százalék, lásd fenti ábra).

A munkanélküliségi kockázatot a továbbtanulási ambíciók és az idegen nyelv ismerete is csökkentik. Az idegen nyelvtudással bírók 21 százaléka volt munkanélküli a kérdezés időpontjában, míg a csak magyarul tudók között ez az adat 30 százalék volt. Az érettségi megszerzése is csökkenti a munkanélküliség esélyét: az érettségizettek 18 százaléka számolt be munkanélküliségről, a csak szakképzettséggel rendelkezőknek viszont 25 százaléka.

Emellett a tanulószerződéses tanulók ritkábban válnak munkanélkülivé: a csak iskolai tanmühelybe járók között 32 százalékot tett ki a munkanélküliek aránya a kérdezések időpontjában, míg a külső céghez járók körében 24 százaléknak, a mindkét lehetőséget megragadók között pedig 22 százaléknak nem volt munkája. 


\section{Összefoglalás}

A felsőoktatás szerkezeti átalakításánál feltétlenül figyelmet kell fordítani a beiskolázási létszámokhoz kapcsolódó problémára. Az elmúlt években a felsőoktatást is elérte a születések számának egykori drasztikus visszaeséséből fakadó létszámcsökkenés: míg a KSH adatai szerint 2010-ben a 18 éves korosztály statisztikai létszáma mintegy 126000 fős volt, 2015-re e korosztály létszáma 105000 főre tehető, ami néhány év alatt csaknem 20\%-os csökkenést jelent(Bángi-MagyarA. et. al., 2009). Ez a trend jelentősen csökkentette és a következő években is csökkenteni fogja a magyar felsőoktatás iránti keresletet, legalábbis ebben a korosztályban. A vélhetően csökkenő hallgatói létszám azonban egyben erőforrás is: a felszabaduló kapacitások jól hasznosíthatóak a felsőoktatás minőségi átalakítása során.

A nemzetközileg versenyképes gazdaság alapjául szolgáló humán eröforrás biztosításában Magyarországnak egy igen fontos problémával kell szembenéznie. A munkaerő tovább- és átképzése az élethosszig tartó tanulás különböző formáin keresztül történik, és e tekintetben hazánk igen kedvezőtlen mutatókkal rendelkezik. Ez a nem-formális képzésben való részvétel adataival illusztrálható a legérthetőbben.

Hazánkban a 25-34 éves korosztály 10\%-a, míg az 55-64 éves korosztály 2\%-a vesz részt nem formális képzésben, ami alig negyede az OECD átlagnak (37\% ill. 23\%). Az élethosszig tartó tanulás problémáinak megoldása nem elsősorban a felsőoktatás feladata, a szerkezeti átalakítás során azonban erre a kihívásra a felsőoktatásnak is válaszolnia kell.

Magyarországi munkavállalók szakmaelhagyását vizsgálva (Csehné Papp I. - Hajós L., 2014)kiderült, hogy érthető módon az eredmények szoros összefüggést mutatnak a pályaelhagyás ideje és a szakmai megbecsülés, illetve a pályaelhagyás ideje és az anyagiakkal való megelégedettség mértéke között.

\section{Következtetések}

Célkitüzés a képzési programok átstrukturálása annak érdekében, hogy minden hallgató a képességeinek és lehetőségeinek megfelelő, a munkaerőpiacon értékes tudásra tegyen szert. A szakképzési rendszerből történő felsőoktatási átmenet biztosítására, új képzési szerkezet és alapképzési típus kialakítására (pl. üzemmérnök, üzemgazdász), azaz a munkaerő-piaci részvételhez jobban alkalmazkodó képzési formákra van szükség.

\section{Akciók:}

- Az ágazati szabályozás szintjén szükséges kialakítani a szakképzésre és a munkatapasztalatra építő alapképzési kimenetet (pl. üzemmérnök, üzemgazdász), több fajta továbbképzési és egyúttal mesterszakos kimeneti formát is biztosítva.

- A felsőbb szintủ képzésből az alacsonyabb képzési szintbe való bekapcsolódás lehetőségének megteremtése, így biztosítva megfelelő szintü kimenetet.

- Duális képzések elindítása, a felsőoktatás rendszerébe tartozó szakképzések profiltisztítása, a felsőoktatás rendszerébe tartozó rövid ciklusú, valamint felsőfokú tovább- és átképzési programok indítása az intézményi és az ágazati szabályozás felelösségi körében.

- A jelenlegi felsőoktatási szakképzések szakmai színvonalának emelése mellett annak elérése, hogy ezen gyakorlatorientált képzések is biztosítsanak felsőfokú végzettséget, adott esetben biztosítva annak lehetőségét, hogy a szakiskolából, szakközépiskolából jelentkező hallgatók - megfelelő színvonalú középiskolai eredmény esetén - kerüljenek 
be ezen képzésekre, továbbá átvétellel azon hallgatók, akik a klasszikus értelemben vett alapképzést, osztatlan képzést nem tudják elvégezni.

- A doktori képzésre felkészítő 4 féléves mesterképzések mellett olyan 2-4 féléves, gyakorlatorientált mesterképzések létesítése, melyek nem a doktori képzésre, hanem a magasabb minőségü ismeretek biztosítása révén a még magasabb minőségü munkavégzésre készítenek fel.

\section{Irodalomjegyzék}

1. Anwar M. (2011): A felsőoktatás minősége európai dimenzióban In: Minőség és Megbízhatóság 2011/3

2. Bálint J. - Polónyi I. Siklós B. (2013): A felsőoktatás minősége, Felsőoktatási Kutatóintézet, Budapest

3. Bángi-Magyar A. et. al. (2009): AVIR kézikönyv, Educatio Társadalmi Szolgáltató Nonprofit Kft., Budapest

4. Csehné Papp I. - Hajós L. (2014): Education and working life in Hungary, Acta Technica Corviniensis - Bulletin of Engineering, 2

5. Csehné Papp I. (2014): Munkaerő-piaci álmok, In: Kulturális és társadalmi sokszínűség a változó gazdasági környezetben. szerk. Karlovitz J T, International Research Institute, Komarno

6. Czeglédi Cs.-Juhász T. (2015): „Mit várunk el a pályakezdőktől?” Vélemények és szempontok a cégek oldaláról, (megjelenés alatt Studia Mundi-Economica tudományos on-line folyóirat, 2015)

7. Hrubos I. (2012): Felsőoktatás-politika, Budapesti Corvinus Egyetem, Budapest

8. Juhászné Klér A. (2013): Szociális készségek és interperszonális személyiségjellemzők szerepe a pályafejlödésben - avagy hogyan ítélik meg önmagukat az egyetemisták? In: Karlovitz J T, Torgyik J (szerk.) Vzdelávanie, výskum a metodológia [Oktatás, kutatás és módszertan]. Komárno: International Research Institute

9. Topár J. (2008): Felsőoktatási intézmények minőségbiztosítása In: Educatio 17. évf. 1. sz.

10. 2011. évi CCIV. törvény a nemzeti felsőoktatásról

11. 19/2012. (II. 22.) Korm. rendelet a felsőoktatási minőségértékelés és -fejlesztés egyes kérdéseiről

\section{Internet:}

1. http://www.mab.hu/web/index.php?lang=hu

2. http://europa.eu/legislation_summaries/education training youth/lifelong learning/c1 1067 hu.htm

3. http://europa.eu/legislation_summaries/education_training_youth/youth/ef0024_hu.ht $\underline{m}$

4. http://ec.europa.eu/social/main.jsp?langId=hu\&catId=950

5. http://www.kormany.hu/hu/emberi-eroforrasok-miniszteriuma/felsooktatasert-felelosallamtitkarsag

6. http://www.kormany.hu/download/d/90/30000/felsoktatasikoncepcio.pdf 